\title{
Cholinesterase Inhibition in the Acute Toxicity of Alkyl-Substituted 2-Aminoethanols ${ }^{1}$
}

\author{
Rolf Hartung and Herbert H. Cornish \\ The University of Michigan, Department of Industrial Health, \\ School of Public Health, Ann Arbor, Michigan 48104
}

Received December 6, 1967

The alkyl-substituted 2-aminoethanols have found widespread use in industry as absorbants, emulsifying agents, flotation agents, curing agents, and as chemical intermediates.

The acute toxicity of some of these compounds has been investigated by Smyth et al. (1954) and by Cornish (1965).

The 2-aminoethanols (Fig. 1A) may form quaternary amines (Fig. 1B) which are related to choline (Ch) (2-trimethylaminoethanol) (Fig. $1 \mathrm{C}$ ). Some of the substituted

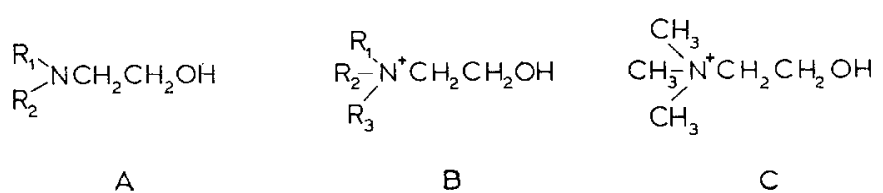

FIG. 1. Alkyl-substituted 2-aminoethanols.

2-aminoethanols can act as natural precursors in choline synthesis. du Vigneaud et al. (1946) showed that 2-methylaminoethanol (MeAE) and 2-dimethylaminoethanol ( $\mathrm{Me}_{2} \mathrm{AE}$ ) could act as choline precursors, and Artom (1964) confirmed that phosphatidyl MeAE could be methylated by rat liver preparations. Bremer et al. (1960) have proposed that phosphatidylethanolamine is converted to choline by stepwise methylation.

Some compounds which are not normally precursors of choline may also enter into the metabolic pathways of choline synthesis. Bell et al. (1964) reported that 2-ethylaminoethanol (EtAE) and 2-diethylaminoethanol $\left(\mathrm{Et}_{2} \mathrm{AE}\right)$ were methylated in vivo to their respective choline analogs.

Burgen et al. (1956) demonstrated that ethylcholine ( $\mathrm{EtCh})$, diethylcholine $\left(\mathrm{Et}_{2} \mathrm{Ch}\right)$, triethylcholine $\left(\mathrm{Et}_{3} \mathrm{Ch}\right)$, and $n$-butylcholine $(\mathrm{BuCh})$ could be acetylated readily by a choline acetylase preparation from rat brain. The same enzyme preparation acetylated $\mathrm{AE}$ and MeAE to a slight extent. Dauterman and Mehrotra (1963) reported that a similar enzyme preparation could acetylate $N$-alkyl substituted cholinc analogs which contained two methyl groups. Mehrotra and Dauterman (1963) also reported that

${ }^{1}$ Portions of this paper were presented at the Society of Toxicology meetings in 1966 and 1967. 
many $N$-alkyl analogs of acetylcholine could be hydrolyzed by rat brain cholinesterase. It is apparent that many of the alkyl-substituted 2-aminoethanols are able to enter into some of the metabolic pathways of choline metabolism.

Many of the physiologic effects of the alkyl-substituted 2-aminoethanols also appear to relate to the normal functions of choline and its metabolites.

Hauschild (1943) reported reductions in blood pressure after EtAE and $\mathrm{Et}_{2} \mathrm{AE}$ in cats. Kraatz et al. (1950) reported that $\mathrm{Et}_{2} \mathrm{AE}$ stimulates the excised rabbit intestine or uterus and causes bronchoconstriction in isolated guinea pig lungs.

$\mathrm{Me}_{2} \mathrm{AE}$ has been used clinically in the treatment of anxiety (Malitz et al., 1967), on the rationale that it would increase endogenous acetylcholine.

Exposures of dogs to $12 \mathrm{ppm}$ of AE vapor resulted in excitation followed by depression (Weeks et al., 1960).

Intraperitoneal injection of $\mathrm{Ch}$ results in chromodacryorrhea, salivation, convulsions, and respiratory paralysis (Hodge, 1944).

$\mathrm{Et}_{3} \mathrm{Ch}$ slows the release of acetylcholine and causes a muscular weakness similar to myasthenia gravis (Bowman and Hemsworth, 1965).

According to Bowman and Rand (1962), Ch and EtCh have primarily a depolarizing activity, $\mathrm{Et}_{2} \mathrm{Ch}$ and $\mathrm{Et}_{3} \mathrm{Ch}$ produce a presynaptic blockade, and $\mathrm{BuCh}$ and larger molecules have a curare-like action at the neuromuscular junctions.

Gebber and Volle (1965) have reported that Ch can stimulate the superior cervical ganglion of the cat directly, and Brestkin et al. (1965) reported that Ch could readily inhibit acetylcholinesterase. In addition, Krupka (1965) found that cholinesterase could be inhibited in vitro by various amines, including $\mathrm{Me}_{2} \mathrm{AE}$.

It becomes evident from the preceding discussion that the various alkyl-substituted 2-aminoethanols may produce a wide variety of neurologic effects and that some of these substances may produce several effects simultaneously.

The present study was undertaken as an attempt to correlate the acute oral and intraperitoneal toxicity of these compounds with their ability to inhibit cholinesterase activity in vitro. In selected instances in vivo cholinesterase inhibition was also investigated in brain and red cells of treated animals.

\section{METHODS}

The alkyl-substituted 2-aminoethanols were procured commercially from Eastman Organic Chemicals. Since they are normally quite alkaline, all were neutralized with $\mathrm{HCl}$ to a $\mathrm{pH}$ of $6.8-7.2$ prior to use.

The choline analogs corresponding to some of these aminoethanols were also investigated. These choline analogs were prepared as the iodides by quaternization of the disubstituted 2-aminoethanols with the appropriate alkyl iodide. They were then purified by repeated recrystallization from alcoholic ether.

The acute oral and intraperitoneal toxicities of these compounds were studied in male Sprague-Dawley rats. The statistical analyses of the $\mathrm{LD}_{50}$ 's were done according to Weil (1952).

The in vitro studies utilized a purified enzyme preparation derived from bovine erythrocytes. ${ }^{2}$ The enzyme activity was analyzed by a modification of the electrometric

\footnotetext{
${ }^{2}$ Sigma Chemical Co., St. Louis, Missouri
} 
method of Michel (1949). This modification consisted of a titration of the buffer system with dilute acetic acid, so that the change in $\mathrm{pH}$ could be related to the amount of acetic acid liberated by the enzymatic hydrolysis of the acetylcholine substrate. During the analysis the $\mathrm{pH}$ varied from 7.7 to 7.3 .

The brain and red cell cholinesterase levels were also determined in rats which were sacrificed 10-15 minutes after receiving an intraperitoneal dose of $\mathrm{Me}_{2} \mathrm{AE}$, EtAE, $\mathrm{Bu}_{2} \mathrm{AE}$, or $\mathrm{Bu}_{2} \mathrm{Ch}$. The whole rat brains were removed immediately after sacrifice and homogenized with an equal volume of physiological saline at $0^{\circ}$. Red cells were separated from the plasma by centrifugation and washed twice with physiological saline prior to analysis.

\section{RESULTS}

All the aminoethanols tested inhibited cholinesterase in vitro (Figs. 2-4). Aminoethanol and the monosubstituted 2-aminoethanols were the least inhibitory in character. Relatively high concentrations of inhibitor were required for significant inhibition (Fig. 2). The disubstituted 2-aminoethanols inhibited cholinesterase at a

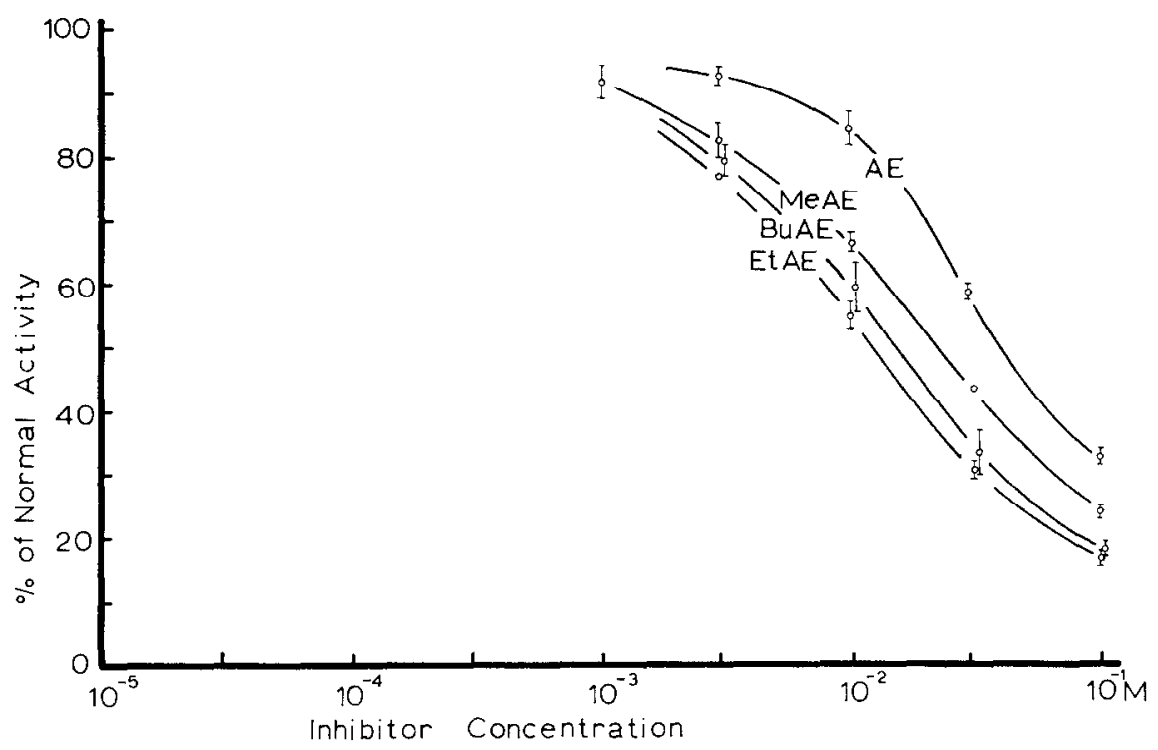

FIG. 2. Acetylcholinesterase inhibition by neutralized monoalkyl-2-aminoethanols.

concentration nearly an entire order of magnitude below that of the comparable monosubstituted compounds (Fig. 3). Diethanolamine ( $\left.\mathrm{AE}_{2}\right)$ occupied an intermediate position, and $\mathrm{Bu}_{2} \mathrm{AE}$ was the most inhibitory of the disubstituted 2-aminoethanols.

Choline and the ethyl-substituted cholines inhibited at about the same level as some of the disubstituted 2-aminoethanols. The inhibition curves of $\mathrm{Ch}, \mathrm{EtCh}, \mathrm{Et}_{2} \mathrm{Ch}$, and $\mathrm{Et}_{3} \mathrm{Ch}$ overlapped closely and have therefore been presented in general outline only (Fig. 4). The standard errors on these curves were comparable to those of the other cholinesterase inhibition curves in this study. $\mathrm{BuCh}$ and $\mathrm{Bu}_{2} \mathrm{Ch}$ were the most inhibitory choline analogs tested. 


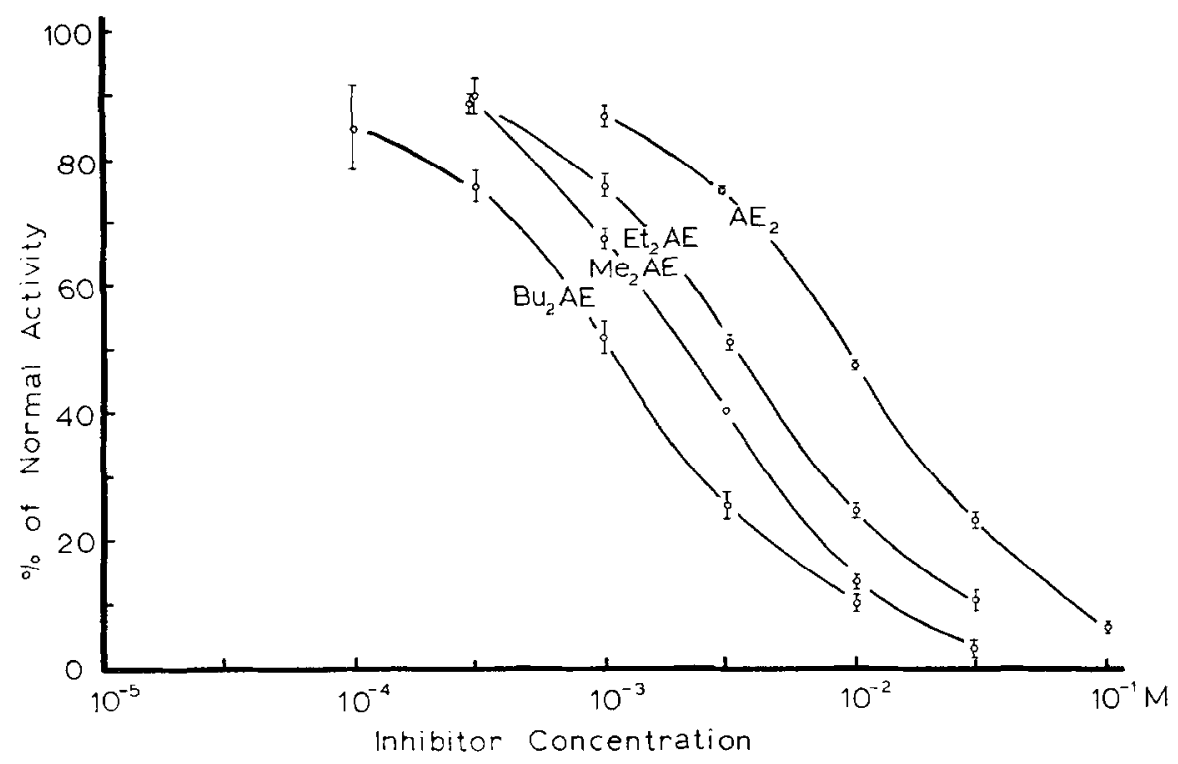

FIG. 3. Acetylcholinesterase inhibition by dialkyl-2-aminoethanols.

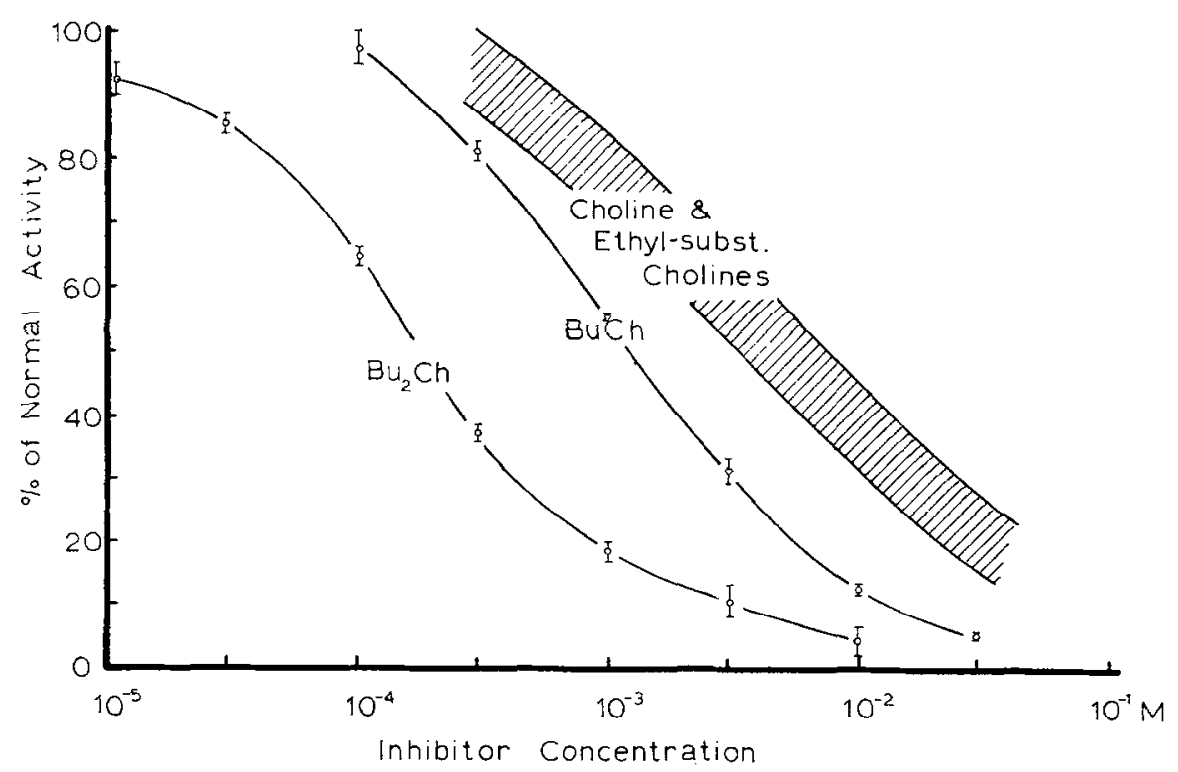

FIG. 4. Acetylcholinesterase inhibition by $\mathrm{N}$-alkyl-substituted choline analogs.

In order to examine any quantitative relationship between in vitro cholinesterase inhibition and the acute toxicity of these compounds, their oral and intraperitoneal toxicities were determined (Table 1).

The oral $\mathrm{LD}_{50}$ 's are uniformly higher than the intraperitoncal $\mathrm{LD}_{50}$ values. Choline analogs exhibit a particularly large differential between oral and intraperitoneal 
TABLE 1

LD $_{50}$ 's OF Substituted 2-Aminoethanols

\begin{tabular}{llllll}
\hline Compound & $\mathrm{R}_{1}$ & $\mathrm{R}_{2}$ & $\mathrm{R}_{3}$ & Oral $\mathrm{LD}_{50}(\mathrm{~g} / \mathrm{kg})$ & I.p. $\mathrm{LD}_{50}(\mathrm{~g} / \mathrm{kg})$ \\
\hline $\mathrm{AE}$ & $\mathrm{H}$ & $\mathrm{H}$ & $\mathrm{H}$ & $3.32(2.71-4.07)^{a}$ & $0.981(0.887-1.08)^{a}$ \\
$\mathrm{MeAE}$ & $\mathrm{CH}$ & $\mathrm{H}$ & $\mathrm{H}$ & $3.36(2.37-4.75)$ & $1.33(1.06-1.69)$ \\
$\mathrm{EtAE}$ & $\mathrm{C}_{2} \mathrm{H}_{5}$ & $\mathrm{H}$ & $\mathrm{H}$ & $1.45(1.19-1.77)$ & $1.17(1.02-1.34)$ \\
$\mathrm{BuAE}$ & $\mathrm{C}_{4} \mathrm{H}_{9}$ & $\mathrm{H}$ & $\mathrm{H}$ & $7.27(6.60-8.00)$ & $0.84(0.65-1.21)$ \\
$\mathrm{Me}{ }_{2} \mathrm{AE}$ & $\mathrm{CH}_{3}$ & $\mathrm{CH}_{3}$ & $\mathrm{H}$ & $6.00(4.75-7.59)$ & $1.08(0.81-1.44)$ \\
$\mathrm{Et}_{2} \mathrm{AE}$ & $\mathrm{C}_{2} \mathrm{H}_{5}$ & $\mathrm{C}_{2} \mathrm{H}_{5}$ & $\mathrm{H}$ & $5.65(3.49-9.14)$ & $1.22(0.88-1.71)$ \\
$\mathrm{Bu}_{2} \mathrm{AE}$ & $\mathrm{C}_{4} \mathrm{H}_{9}$ & $\mathrm{C}_{4} \mathrm{H}_{9}$ & $\mathrm{H}$ & $1.78(1.33-2.39)$ & $0.144(0.091-0.219)$ \\
$\mathrm{Ch}$ & $\mathrm{CH}_{3}$ & $\mathrm{CH}_{3}$ & $\mathrm{CH}_{3}$ & $6.64(5.42-8.13)$ & $0.400(0.269-0.595)$ \\
$\mathrm{EtCh}$ & $\mathrm{C}_{2} \mathrm{H}_{5}$ & $\mathrm{CH}_{3}$ & $\mathrm{CH}_{3}$ & $6.93(5.89-8.16)$ & $0.297(0.215-0.420)$ \\
$\mathrm{Et}_{2} \mathrm{Ch}$ & $\mathrm{C}_{2} \mathrm{H}_{5}$ & $\mathrm{C}_{2} \mathrm{H}_{5}$ & $\mathrm{CH}_{3}$ & $2.00(1.37-2.99)$ & $0.332(0.271-0.407)$ \\
$\mathrm{Et}_{3} \mathrm{Ch}$ & $\mathrm{C}_{2} \mathrm{H}_{5}$ & $\mathrm{C}_{2} \mathrm{H}_{5}$ & $\mathrm{C}_{2} \mathrm{H}_{5}$ & $1.00(0.670-1.49)$ & $0.181(0.133-0.247)$ \\
$\mathrm{Bu}_{2} \mathrm{Ch}$ & $\mathrm{C}_{4} \mathrm{H}_{9}$ & $\mathrm{C}_{4} \mathrm{H}_{9}$ & $\mathrm{CH}_{3}$ & $7.88(6.23-9.96)$ & $0.089(0.070-0.112)$ \\
\hline
\end{tabular}

${ }^{a}$ Figures in parentheses denote $95 \%$ confidence intervals.

toxicity, which is probably due to the slower absorption of these highly ionic quaternary amines from the gastrointestinal tract.

When the toxicity data and the inhibitory concentrations are compared on the basis of molar concentrations (Table 2), some interesting trends become evident. As the inhibitory capacity of the substituted 2-aminoethanol increases, there appears to be a

TABLE 2

CORRelation of in Vitro Inhibition of Cholinesterase with the Acute Toxicities of SUBSTITUTED 2-AMINOETHANOLS

\begin{tabular}{lccc}
\hline \multicolumn{1}{c}{ Compound } & $\begin{array}{c}\text { Inhibitor conc. } \\
\text { producing 50\% } \\
\text { inhibition (mm/liter) }\end{array}$ & $\begin{array}{c}\text { Oral LD } \\
(\mathrm{mm} / \mathrm{kg})\end{array}$ & $\begin{array}{c}\text { I.p. } \text { LD }_{50} \\
(\mathrm{~mm} / \mathrm{kg})\end{array}$ \\
\hline $\mathrm{AE}$ & 40 & $54.5^{a}$ & $15.9^{b}$ \\
$\mathrm{MeAE}$ & 23 & 44.7 & 17.7 \\
$\mathrm{EtAE}$ & 13 & 16.3 & 13.2 \\
$\mathrm{BuAE}$ & 15 & 61.9 & 7.17 \\
$\mathrm{Me}_{2} \mathrm{AE}$ & 1.9 & 67.3 & 12.1 \\
$\mathrm{Et}_{2} \mathrm{AE}$ & 3.1 & 48.2 & 10.4 \\
$\mathrm{Bu}{ }_{2} \mathrm{AE}$ & 1.1 & 10.3 & 0.831 \\
$\mathrm{Ch}$ & 6.2 & 28.8 & 1.73 \\
$\mathrm{EtCh}^{\mathrm{Et}} \mathrm{Ch}$ & 4.0 & 28.3 & 1.21 \\
$\mathrm{Et}_{3} \mathrm{Ch}$ & 4.5 & 7.72 & 1.28 \\
$\mathrm{Bu}_{2} \mathrm{Ch}$ & 6.2 & 3.68 & 0.663 \\
$\mathrm{BuCh}$ & 0.18 & 25.0 & 0.282 \\
\hline
\end{tabular}

${ }^{a}$ Correlation between median inhibitory concentration and oral $\mathrm{LD}_{50} r=0.378, p<0.1$.

${ }^{b}$ Correlation between median inhibitory concentration and i.p. $\mathrm{LD}_{50} r=0.676, p<0.01$. 
concurrent increase in the intraperitoneal toxicity, resulting in a very significant correlation coefficient of $r-0.676$. When the oral $\mathrm{LD}_{50}$ values are compared on the same basis, they generate a correlation coefficient of $r=0.378$, which has only marginal significance.

When four of the aminoethanols were given intraperitoneally, they produced moderate but significant depressions in brain cholinesterase activities (Table 3). A significant depression in red cell cholinesterase activity was only noted for $\mathrm{Me}_{2} \mathrm{AE}$.

TABLE 3

Cholinesterase Levels after an Intraperttoneal LD $_{50}$ Dose of Some Substituted 2-AMINOETHANOLS

\begin{tabular}{lcc}
\hline Compound & $\begin{array}{c}\text { Brain cholinesterase } \\
\text { (percent of normal) }\end{array}$ & $\begin{array}{l}\text { RBC cholinesterase } \\
\text { (percent of normal) }\end{array}$ \\
\cline { 2 - 3 } Control & $100 \pm 2.4$ & $100 \pm 6.7$ \\
$\mathrm{EtAE}$ & $83.5 \pm 2.4^{a}$ & $75.2 \pm 7.5$ \\
$\mathrm{Me}_{2} \mathrm{AE}$ & $82.4 \pm 5.8^{a}$ & $54.9 \pm 6.7^{a}$ \\
$\mathrm{Bu}_{2} \mathrm{AE}$ & $82.4 \pm 5.8^{a}$ & $100 \pm 8.1$ \\
$\mathrm{Bu}_{2} \mathrm{Ch}$ & $88.0 \pm 1.8^{b}$ & $75.0 \pm 10.1$ \\
\hline
\end{tabular}

$a p<0.01$.

${ }^{b} p<0.05$.

\section{DISCUSSION}

The data presented in this paper indicate that neutralized $N$-alkyl substituted 2 aminoethanols inhibit cholinesterase in vitro. Inhibition increases as the degree of substitution and the molecular size of the nitrogenous head of the aminoethanol molecule increase. When the concentrations of substituted aminoethanols producing $50 \%$ inhibition in vitro are compared with their intraperitoneal $\mathrm{LD}_{50}$ doses on a molar basis, these two variables are found to correlate well on a statistical basis.

The increase in molecular size at the nitrogenous head has several important consequences. As the size of the substituent groups increases, the potential for van der Waals' interactions with the protein surface increases. Any increase in binding force with the enzyme near an active site would express itself in increased enzyme inhibition. When the log median inhibitory concentrations of the substituted 2-aminoethanols are compared on the basis of the number of substituent carbon atoms (Fig. 5), one notes that a great number of these points lie on or in very close proximity to a straight line.

In those cases, these data correlate closely with those of Bergmann (1955), who found linearly increasing inhibition of cholinesterase by compounds in the series $\left(\mathrm{CH}_{3}\right)_{3} \mathrm{~N}\left(\mathrm{CH}_{2}\right)_{n} \mathrm{CH}_{3}$ as $n$ was increased. In the series presented in Fig. 5, not all substituted 2-aminoethanols conform to the straight-line relationship. In the case of the ethyl-substituted quaternary amines, anomalous behavior in activity series had been noted previously by Collier and Exley (1963). The reasons for these anomalies are not entirely apparent. It is likely that forces other than van der Waals' interactions predominate disproportionately in these cases. 
It has been suggested that coulombic attraction between the cationic head of a quaternary amine and an anionic site on the enzyme are of primary importance in the enzyme-substrate interactions (Wilson and Bergmann, 1950). As the nitrogenous head of the aminoethanol moiety in this study is substituted with an increasing number of

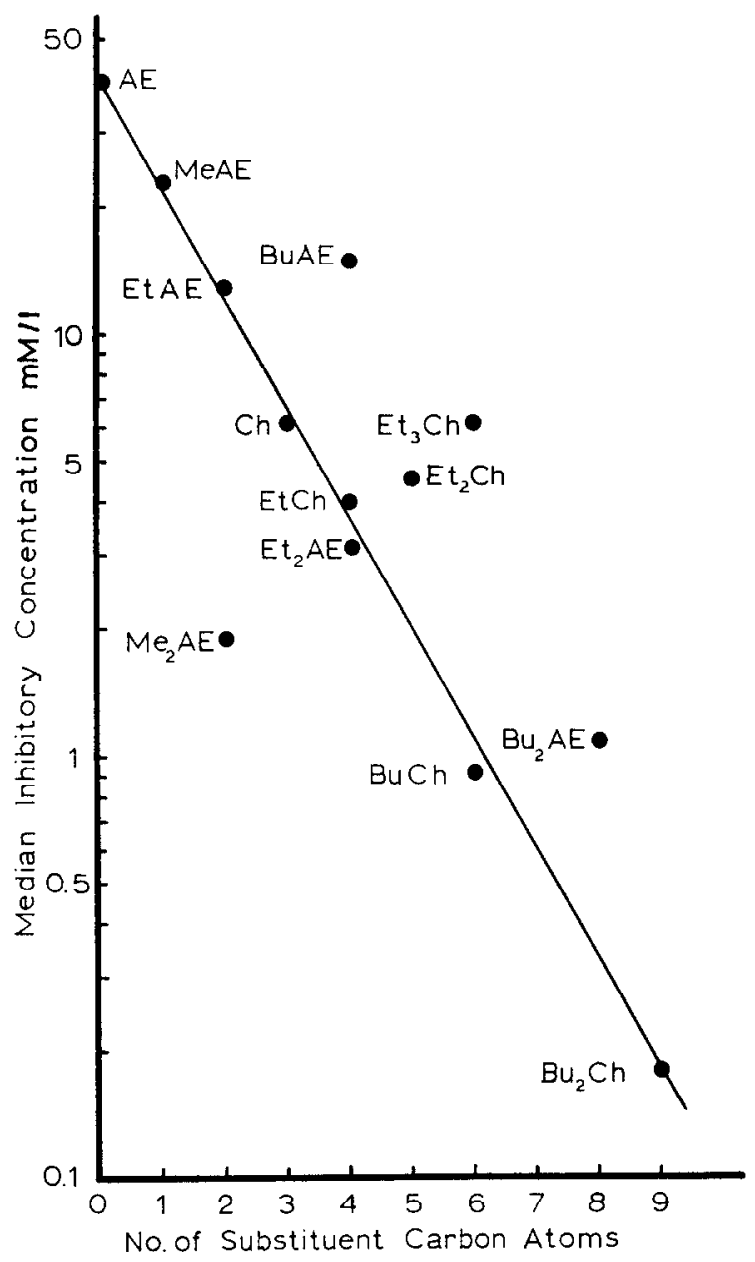

FIG. 5. Relationships of median inhibitory concentrations to the size of the substituent group on the nitrogenous head of the 2-aminoethanol molecule.

carbon atoms, there is an induction of electrons from the substituent chains toward the positive nitrogen atom. Therefore, the effective positive charge on the nitrogen atom decreases as the size and number of the alkyl substituents increases. As a consequence, the charge density of the cationic head decreases, and the coulombic attraction between this cationic head and the anionic site on the enzyme decreases also. In addition, steric effects of the substituent groups may further limit the approach of the two ionic sites, further limiting the degree of coulombic attraction. 
It is, therefore, apparent that the inhibition of cholinesterase produced by the alkylsubstituted 2-aminoethanols cannot be readily explained by changes in anioniccationic attraction. However, coulombic attractions combined with steric effects may well explain the divergences of some substituted 2-aminoethanols from the model based on van der Waals' interactions.

The three aminoethanols which were tested in vivo produced significant decreases in brain cholinesterase in rats within 15 minutes after an intraperitoneal LD $_{50}$ dose. The observed decreases in brain cholinesterase were comparable in magnitude to those rcported by Murphy (1967) in guinea pigs 15 minutes after $400 \mathrm{mg} / \mathrm{kg}$ i.p. of Malathion. While organophosphates often produce much higher levels of in vivo inhibition than those indicated here (Koppanyi and Karczmar 1951), the work of McIsaac and Koelle (1959) had indicated that the more lipid-soluble organophosphates readily inhibit both functional and reserve $\mathrm{AChE}$, while the quaternary amines preferentially inhibit functional AChE. Since only the activity level of functional AChE has immediate physiologic significance, it is apparent that the measurement of total brain cholinesterase inhibition (functional + reserve) may underestimate the physiologic effect, especially in the case of quaternary amines.

The present data strongly suggest that cholinesterase inhibition is a factor in the acute toxicity of many alkyl-substituted 2-aminoethanols.

\section{SUMMARY}

The acute oral and intraperitoneal toxicity of a series of alkyl-substituted 2-aminoethanols was studied in relation to cholinesterase inhibition. All the 2-aminoethanols studied inhibited cholinesterase in vitro. The level of in vitro inhibition was related to the number of carbon atoms attached on the nitrogenous head of the 2-aminoethanol molecule. The median inhibitory concentrations correlate well with the $\mathrm{LD}_{50}$ data. Intraperitoneal $\mathrm{LD}_{50}$ doses of four alkyl-substituted 2-aminoethanols produced significant reductions in brain cholinesterase in rats.

\section{ACKNOWLEDGMENTS}

The technical assistance of Mr. Krekel E. Green II is gratefully acknowledged. This study was supported, in part, by U.S. Public Health Service Grant UI-00482 from the National Center of Urban and Industrial Health.

\section{REFERENCES}

ARTom, C. (1964). Methylation of phosphatidyl monomethylethanolamine in liver preparations. Biochem. Biophys. Res. Commun. 15, 201-206.

BeLl, O. E., Davis, E. Y., and Strength, D. R. (1964). Ethylated ethanolamines in phospholipids. Federation Proc. 23, 222.

Bergmann, F. (1955). Fine structure of the active surface of cholinesterases and the mechanism of enzymatic ester hydrolysis. Discussions Faraday Soc. 20, 126-134.

Bowman, W. C., and Hemsworth, B. A. (1965). Effects of triethylcholine on the output of acetylcholine from the isolated diaphragm of the rat. Brit. J. Pharmacol. 24, 110-118.

BoWMAN, W. C., and RAND, M. J. (1962). The neuromuscular blocking action of substances related to choline. Intern. J. Neuropharmacol. 1, 129-132.

Bremer, J., Figard, P. H., and GreenBerG, D. M. (1960). The biosynthesis of choline and its relation to phospholipid metabolism. Biochim. Biophys. Acta 43, 477-488. 
Brestkin, A. P., Ivanova, L. A., and Svechnikova, V. V. (1965). The mechanism of choline inhibition of acetylcholine hydrolysis by horse plasma cholinesterase. Biokhimiya 30 , 137-140.

Burgen, A. S. V., Burke, G., and Desbarats-Schonbaum, M. L. (1956). The specificity of brain choline acetylase. Brit. J. Pharmacol. 11, 308-312.

COLLIER, B., and EXLEY, K. A. (1963). Charge delocalization in relation to neuromuscular blocking activity of certain tetraalkylammonium compounds. J. Pharm. Pharmacol. 15, Suppl., 131T-133T.

Cornish, H. (1965). Oral and inhalation toxicity of 2-diethylaminoethanol. Am. Ind. Hyg. Assoc. J. 26, 479-484.

Dauterman, W. C., and Mehrotra, K. N. (1963). The N-alkyl group specificity of choline acetylase from rat brain. $J$. Neurochem. 10, 113-117.

du Vigneaud, V., Chandler, J. P., Simmonds, S., Moyer, A. W., and Cohn, M. (1946). The role of dimethyl- and monomethylaminoethanol in transmethylation reactions in vivo. J. Biol. Chem. 164, 603-613.

GeBber, G. L., and VolLe, R. L. (1965). Ganglionic stimulating properties of aliphatic esters of choline and thiocholine. J. Pharmacol. Exptl. Therap. 150, 67-74.

HausChild, F. (1943). Beitrag zur Frage der pharmakologischen Wirkung einiger aliphatischer Alkyl- und Alkanolamine. Arch. Exptl. Pathol. Pharmakol. 201, 569-579.

Hodge, H. C. (1944). Acute toxicity of choline chloride administered i.p. to rats. Proc. Soc. Exptl. Biol. Med. 57, 26-28.

KopPANYI, T., and KarCZMAR, A. G. (1951). Contribution to the study of the mechanism of action of cholinesterase inhibitors. J. Pharmacol. Exptl. Therap. 101, 327-344.

KraAtz, C. P., Gruber, C. M., JR., and Lisi, A. G. (1950). Observations on diethylaminoethanol. J. Pharmacol. Exptl. Therap. 98, 111-119.

KRUPKA, R. M. (1965). Acetylcholinesterase. Structural requirements for blocking deacetylation. Biochemistry 4, 429-435.

MCIsAaC, R. J., and Koelle, G. B. (1959). Comparison of the effects of inhibition of external, internal and total acetylcholinesterase upon ganglionic transmission. J. Pharmacol. Exptl. Therap. 126, 9-20.

Malitz, S., Wilkins, B., Higgins, J. C., and Kanzler, M. (1967). A pilot evaluation of Deanol in the treatment of anxiety. Current Therap. Res. 9, 261-264.

Mehrotra, K. N., and Dauterman, W. C. (1963). The specificity of rat brain acetylcholinesterase for $\mathrm{N}$-alkyl analogues of acetylcholine. J. Neurochem. 10, 119-123.

Michel, H. O. (1949). An electrometric method for the determination of red blood cell and plasma cholinesterase activity. J. Lab. Clin. Med. 34, 1564-1568.

MURPHY, S. D. (1967). Malathion inhibition of esterases as a determinant of malathion toxicity. J. Pharmacol. Fxptl. Therap. 156, 352-365.

Smyth, H. F., Carpenter, C. P., Weil, C. S., and Pozzani, U. C. (1954). Range finding toxicity data. List V. Arch. Ind. Hyg. Occup. Med. 10, 61-68.

Weeks, M. H., Downing, T. O., Mussfi man, N. P., Carson, T. R., and Groff, W. A. (1960). The effect of continuous exposure of animals to ethanolamine vapor. Am. Ind. Hyg. Assoc. J. 21, 374-381.

WeIL, C. S. (1952). Tables for convenient calculation of median effective dose $\left(\mathrm{LD}_{50}\right.$ or $\left.\mathrm{ED}_{50}\right)$ and instructions in their use. Biometrics 8, 249-263.

Wilson, I. B., and BergmanN, F. (1950). Studies on cholinesterase. VII. The active surface of acetylcholine esterase derived from effects of pH on inhibitors. J. Biol. Chem. 185, 479-489. 